\title{
PORNOGRAFI DAN KEKERASAN TERHADAP PEREMPUAN (KAJIAN KRITIS PANDANGAN FEMINISME RADIKAL)
}

\author{
Atun Wardatun*
}

\begin{abstract}
Some people presume that feminisms are permissive for pornography due to the fact that many women support pornography as an expression of women's freedom. By critical reading and analysis of radical feminism point of view on women's sexuality, this work proves that feminisms are ant pornography. Pornography, since it always puts women as the object, is violence against women, dehumanization, and colonialization of women by the domination of patriarchal society.

There is no way for women to minimize - if not to bring to an endpornography but to start realizing that women are the blamed victims and keep on struggling for gaining equal distribution of power between men and women. Besides, women have to ensure that women are not the only party who have responsibilities for moral degradation of society but at the same time women must be the one as the primary controller for their own body and life.
\end{abstract}

Keywords: Pornografi, Dehumanisasi, Kolonialisasi, Pembagian Power, Feminisme Radikal, Institusionalisasi Hijab.

MENGEMUKANYA penolakan para pemerhati perempuan terhadap Rancangan Undang-Undang Anti Pornografi Pornoaksi (RUU APP) di Indonesia, seakan menempatkan (mempersepsi-salahkan) feminisme sebagai entitas yang

*Penulis adalah dosen pada Fakultas Syari'ah IAIN Mataram, Jln. Pendidikan 35 Mataram. email: atun2004@yahoo.com 
mendukung pornografi dan pornoaksi. Persepsi yang salah terhadap feminisme terjadi baik di kalangan pejuang perempuan (feminisme?) sendiri, maupun berasal dari pihak luar. Ada beberapa kalangan yang atas nama pejuang hak perempuan, menolak mentah-mentah RUU APP dengan dalih hal itu menghalangi kebebasan berekspresi kaum perempuan. Sayangnya penolakan tersebut tidak didasari argumen yang cukup memadai, misalnya bagaimanakah batas-batas kebebasan itu sendiri? Apakah bijak jika menyandingkan pornografi dengan kebebasan berekspresi? Padahal pornografi adalah kejahatan, dan kebebasan berekspresi tentu tidak membenarkan kejahatan sebagai salah satu aspek yang harus diperjuangkan. Sementara itu, pihak-pihak di luar feminis semakin mengukuhkan ketidaksukaannya terhadap kelompok feminisme berdasar pada pendapat apriori yang mencap para feminis sebagai pihak yang pro terhadap tindak asusila dan penghancuran moral bangsa.

Tulisan ini berupaya mendedah dan menyodorkan bagaimana sebenarnya pandangan "genuine" feminisme terhadap isu pornografi. ${ }^{1}$ Selain itu, beberapa catatan juga dikemukakan untuk sekedar mengomentari pandangan feminisme tentang isu terkait. Feminisme radikal dan beberapa eksponen pemikirnya menjadi varian aliran feminis yang banyak dikemukakan dalam makalah ini. Hal ini disebabkan karena feminisme radikal adalah aliran feminis yang banyak membahas perempuan dan seksualitas, di mana isu pornografi menjadi satu dari beberapa subtemanya. Dengan menelusuri pendapat dan corak perjuangan feminisme radikal, ternyata feminisme menolak habis-habisan pornografi. Pornografi sama sekali bukan tentang keindahan tetapi mutlak sebagai sebuah kekerasan terhadap perempuan dan degradasi sifat kemanusiaan perempuan dalam dunia patriarki.

${ }^{1}$ Istilah pornografi yang dipakai dalam tulisan ini juga mencakup istilah pornoaksi yang dikenal dalam konteks Indonesia, sehingga tidak perlu disebutkan pornografi dan pornoaksi. Alasannya dapat dilihat pada bagian lain tulisan ini. 
Kekerasan dan degradasi ini adalah potret betapa posisi tawar perempuan sangat tidak seimbang baik secara sosial, ekonomis, maupun politis di dunia yang masih dimiliki oleh kaum berjenis kelamin lelaki. Oleh karena itu penghapusan pornografi dan pornoaksi adalah sebuah perjuangan yang mendesak bagi perempuan dan sistem kehidupan secara keseluruhan. Pembebasan dunia ini dari pornografi adalah satu dari sekian banyak hak-hak sipil (civil rights) perempuan yang perlu diperjuangkan bersama, bukan saja atas nama perempuan tetapi atas nama kemanusiaan dalam arti yang sesungguhnya.

\section{Sekilas tentang Feminisme Radikal}

Kata radical secara bahasa berarti down to the roots atau kembali ke akar permasalahan. Aliran feminisme radikal terbentuk untuk menggali akar-akar permasalahan munculnya ketidakseimbangan power antara perempuan dan laki-laki. Pada dasarnya, aliran ini berpendapat bahwa pembenahan sistem ketidakadilan antara dua jenis kelamin tidak bisa dilakukan hanya dalam tataran struktural atau reformasi hukum sebagaimana yang diusung oleh feminisme liberal, tetapi harus dilakukan pada tataran kultural dan perempuanlah yang harus memulainya. ${ }^{2}$

Arah perjuangan feminisme radikal yang bersifat kultural tersebut berupaya menumbuhkan gender awareness pada tataran

2Lihat Judith Lorber, Gender Inequality: Feminist Theories and Practice (California: Roxbury Publishing Company, 2001), 77-88. Walaupun terkesan bertentangan dengan feminisme liberal, feminisme radikal, dalam batas tertentu, sebenarnya muncul untuk menambah analisis feminisme liberal. Dalam pandangan feminisme liberal, kesetaraan perempuan dan laki-laki diupayakan dengan menciptakan gender neutral world (dunia yang netral gender), memfokuskan isu dunia patriarki pada lingkungan keluarga, dan pembenahan struktural (aturan hukum). Bagi aliran ini, menciptakan genderneutral world adalah sebuah pengingkaran terhadap sifat keunikan baik lakilaki maupun perempuan. Masing-masing laki-laki dan perempuan memang berbeda walaupun perbedaan itu tidak lalu menjadi alasan untuk menerima ketidakadilan. 
sosial. Pada tingkat yang paling radikal, aliran ini menginginkan agar perjuangan perempuan dimotori oleh dan dikhususkan untuk perempuan itu sendiri. Hal inilah yang kemudian memicu munculnya kritik habis-habisan terhadap aliran ini. Aliran ini tentu punya alasan tersendiri bagi maksudnya menciptakan dunia perempuan. Untuk sekian lama dunia dan kehidupan lebih ditentukan oleh suara laki-laki. Ide, naluri, suara perempuan sama sekali tidak diperhitungkan baik dalam kancah politik, produksi ilmu pengetahuan, perputaran dunia industri, maupun seluk-beluk penelitian sehingga kehidupan perempuan selalu menjadi obyek yang ditentukan sepihak oleh kaum laki-laki. Perempuan selalu teralienasi bahkan untuk menentukan dan memberi arah bagi kehidupan mereka sendiri. Saatnya perempuan didengarkan. Mendengarkan suara perempuan harus murni berasal dari perempuan, tidak dicampuri oleh pandangan sexisme laki-laki. Muncullah kemudian pusat-pusat kajian wanita (PSW) atau women's studies di berbagai perguruan tinggi, yang banyak melibatkan kaum perempuan, karena perempuan sudah jengah untuk terus ditentukan arah hidupnya oleh laki-laki.

Golongan feminisme radikal tidak setuju bila pendekatan yang dipakai oleh pejuang feminisme lebih difokuskan pada tataran legal-formal. Bagi aliran ini hukum apapun adalah produk dari kepentingan pihak yang berkuasa. Selama dunia ini masih dipegang kendalinya oleh pihak laki-laki maka hukum pun pasti akan mewakili kepentingan laki-laki. ${ }^{3}$ Audre Lorde, salah seorang tokoh aliran ini mengatakan bahwa "the master's tools will never dismantle the master's house." (senjatanya seorang tuan tidak akan pernah menghancurkan rumah sang tuan itu sendiri). ${ }^{4}$

${ }^{3}$ Lebih jauh tentang masalah ini, dapat di lihat pada D. Kelly Weisberg, "Introduction" dalam Feminist Legal Theory: Foundations, (Philadelphia: Temple University Press, 1997), dan Catherine A. MacKinnon, Toward a Feminist Theory of the State (Cambridge: Harvard University Press, 1989)

${ }^{4}$ Powerful Quotation yang selalu dialunkan oleh pejuang feminisme radikal. Lihat Audre Lorde, "The Master's Tools Will Never Dismantle the Master's 
Berdasarkan periodesasi kelahiran, feminisme radikal masuk menjadi kelompok second wave feminism (feminisme gelombang kedua) yang kemunculanya ditandai dengan lahirnya karya monumental Simone de Beauvoir's yang berjudul The Second Sex pada tahun 1949 di Perancis. Karya itulah yang memulai munculnya analisis yang membedakan konsep gender dan sex. Berdasarkan kategorisasi corak perjuangan, aliran ini termasuk dalam kelompok gender resistance feminism yaitu aliran feminis yang berjuang melawan penindasan dan eksploitasi perempuan pada kehidupan sosial yang bias gender, khususnya mengenai isu seksualitas, kekerasan, dan representasi kultural mengenai perempuan. Selain aliran ini, yang termasuk juga dalam aliran ini adalah feminisme psikoanalitis dan feminisme standpoint. ${ }^{5}$

Singkatnya, menurut aliran ini, beberapa sumber ketidakadilan gender adalah: 6

a. Sistem penindasan terhadap perempuan oleh kaum laki-laki (sistem patriarkhi) yang selalu mendiskriminasikan perempuan;

House," dalam This Bridge Called My Back: Writings by Radical Women of Color, ed. Cherrie Moraga dan Gloria Anzaldua (New York: Kitchen Table/Women of Color Press, 1983), 98-101. Ketidaksetujuan ini tampaknya, menurut hemat penulis, bukan berarti penolakan. Aliran ini hanya menyangsikan jika hukum atau pendekatan politis saja bisa berbuat banyak untuk menciptakan dunia yang lebih berkeadilan bagi perempuan, ketika cara pandang dunia patriarkhi sudah begitu kuat berakar tidak hanya pada tataran politik-struktural, tetapi juga individual-kultural. Bagi penulis, munculnya aliran ini yang notabene setelah kehadiran feminisme liberal tentu menentukan bagaimana corak analisis aliran ini. Sebagai sebuah aliran yang muncul kemudian, tentu mereka tidak mungkin memunculkan corak yang sama dengan feminisme liberal yang merupakan pendahulunya. Mereka perlu menunjukkan karakterisitik khusus perjuangan mereka sendiri dengan mengusulkan pendekatan kultural.

${ }^{5}$ Lihat Lorber, Gender Inequality..., 9-10. Kategorisasi feminisme berdasarkan corak dan teori perjuangannya dibedakan menjadi tiga, yaitu gender reform feminism, gender resistance feminism dan gender rebellion feminism.

'Ibid., 77. 
b. Kekerasan dan kontrol laki-laki terhadap perempuan;

c. Pengabsahan penindasan terhadap perempuan melalui hukum, agama, dan lembaga-lembaga sosial lainnya;

d. Objektifikasi tubuh perempuan melalui iklan-iklan, mass media, dan produksi-produksi industri lainnya;

e. Eksploitasi perempuan melalui pornografi dan prostitusi.

Dari poin-poin di atas, nampak bahwa menurut pandangan aliran ini, perempuan adalah korban dari budaya patriarkhi yang terjelma dalam berbagai bentuk. Budaya patriarkhi ini didukung oleh berbagai institusi, di mana agama adalah salah satunya. Oleh karenanya, aliran ini juga mengusung kepentingan perempuan lewat perang terhadap teks-teks agama yang mendiskreditkan perempuan. Satu yang perlu di catat, bahwa keinginan aliran ini untuk menciptakan dunia sendiri, dunia yang ditentukan oleh suara perempuan karena pesimisme aliran ini melihat begitu kuat-berakarnya budaya patriarkhi sepanjang perempuan dan laki-laki masih berada dalam satu 'ruang'.

Corak radikalisme feminis juga mewarnai pemikiran dan aksi para feminis muslim. Sebut saja misalnya Fatimah Mernissi yang aktif mendebat konsep ruang yang mendiskriminasi perempuan dalam tradisi Islam. Konsep ruang itu sendiri menurutnya adalah perpanjangan dari konsep hijab (penghalang) yang diperluas menjadi sistem pengurungan (confinement) perempuan di dalam rumah. Seksualitas perempuan dituduh sebagai sumber masalah yang oleh karenanya perlu dibatasi sedemikian rupa. Riffat Hassan dan Aminah Wadud yang berupaya mereinterpretasi teks-teks keagamaan untuk menggali prinsip-prinsip egaliterian dalam ajaran Islam. Di Indonesia, aliran ini terwakili oleh corak pemikiran Nasaruddin Umar, Hosein Muhammad, Zaitunah Subhan, dan lain-lain.

\section{Mendefinisikan Pornografi}

Definisi pornografi tidak sekonkret dan sefamiliar tampilannya dalam kehidupan sehari-hari. Dalam prakteknya, 
orang mungkin dengan sangat mudah menuding hal-hal tertentu sebagai pornografi, tetapi ketika sampai pada tataran pendefinisian, kata pornografi seakan sangat sulit untuk diketengahkan. Definisi-definisi yang ditawarkan oleh feminisme radikal mengenai pornografi juga sangat umum dan abstrak. Untuk kepentingan bahasa hukum, misalnya, definisi-definisi tentang pornografi berikut ini sungguh tidak memadai: ${ }^{7}$

a. Pornografi adalah eksploitasi sexual terhadap perempuan.

b. Pornografi adalah memanfaatkan hubungan seks untuk mengintimidasi dan mengontrol perempuan dan anak-anak atau siapa saja yang bisa terperangkap dalam situasi serupa.

c. Pornografi adalah subordinasi seksual secara nyata terhadap perempuan yang telah terskenario sedemikian rupa, dari yang berbentuk dehumanisasi terhadap perempuan (menempatkan perempuan sebagi objek dan barang komoditi) maupun dalam bentuk ketika perempuan itu tidak menunjukkan reaksi penolakan ketika diperkosa.

Beberapa pengertian istilah pornografi tersebut di atas mungkin dapat dirangkum bahwa menurut feminisme radikal, pornografi adalah sistem subordinasi yang berlaku di mana saja terhadap perempuan oleh laki-laki melalui kekerasan dan eksploitasi seksual (a worldwide system of subordination of women by men through violence and sexual exploitation).

Tampaknya beberapa definisi pornografi yang ditawarkan di atas hanya menggarisbawahi pornografi sebagai tindakan yang memanfaatkan perempuan sebagai obyek seksual semata. Objektifikasi perempuan secara seksual ini lahir dari ketidakberdayaan perempuan berfungsi sebagai mesin pengontrol, bahkan untuk tubuhnya sendiri, yang lalu berakibat pada mapannya subordinasi perempuan. Ternyata beberapa

"Marcia Ann Gilespie et.al, "Where do We Stand on Pornography," dalam Debating Sexual Correctness: Pornography, Sexual Harrasment, Date Rape and The Politics of Sexual Equality, ed. Adele M. Stan (New York: Dell Publishing, 1995), 51-2. 
pengertian pornografi yang ditawarkan di atas overlap dengan definisi pornoaksi. Di Indonesia, pornografi lebih sempit artinya, lebih pada gambar-gambar, atau tampilan-tampilan visual yang berbau porno. Kalau porno atau asusila itu berkait dengan tindakan, maka itu dinamakan dengan pornoaksi. Dalam kamus bahasa Inggris memang kata pornoaction tidak ditemukan. Biasanya istilah pornography atau obscenity lebih umum digunakan.

Sebagai sebuah penjelasan awal yang menitikberatkan kekerasan kepada perempuan, arti pornografi sebagaimana yang ditawarkan oleh feminisme radikal di atas mungkin cukup. Tetapi untuk kepentingan yang lebih besar, misalnya sebagai dasar menuding perbuatan tertentu sebagai pornografi, maka pengertian-pengertian tersebut sangatlah tidak memadai. Lebih dari itu, aliran ini terlalu menitik-tekankan korban pornografi itu selalu perempuan dan oleh karenanya tersurat juga bahwa pelakunya selalu laki-laki. Misalkan kasus Anjasmara yang difoto bugil baru-baru ini hendak dikategorikan sebagai pornografi tentu lalu tidak ter-cover oleh keterbatasan pengertian tersebut.

Kesulitan mendefinisikan pornografi serta memberikan batasan-batasan inilah yang lalu mengganjal upaya meminimalisir pornografi lewat perangkat hukum. Di satu sisi hukum memerlukan kepastian batasan, pengertian, dan aturan. Sementara di sisi lain, pada konteks Indonesia misalnya, batasanbatasan itu sulit terbentuk di hadapan keragaman budaya, penafsiran, dan kepentingan berbagai pihak.

\section{Mendebat Politik Ketimpangan Seksual}

Beberapa eksponen feminisme radikal sangat anti pornografi. Sebut saja di antaranya Andrea Dworkin, Catharine A. MacKinon, dan Ellen Willis. Secara umum, mereka memandang pornografi sebagai bentuk kekerasan terhadap perempuan (Pornography is not really about sex but about violence against women) yang juga secara langsung mendorong tingginya angka perkosaan 
terhadap perempuan (pornography is the theory, rape is the practice). ${ }^{8}$ Pornografi oleh karenanya adalah penghinaan dan perendahan derajat perempuan. Perempuan tidak lagi dipandang sebagai manusia dan subyek dalam dunia mereka tetapi semata-mata sebagai benda yang bebas diobyektifikasi dan dikomodifikasi untuk kepentingan dunia patriarkhi. Pada poin inilah pornografi sebenarnya adalah politik dunia patriarkhi yang mencerminkan ketidakseimbangan posisi tawar antara dua jenis seks yang berbeda yang lagi-lagi perempuan berposisi sebagai pelaku yang dibius sekaligus sebagai korban yang selalu disalahkan.

Dalam tradisi Islam, sebagaimana yang dilansir oleh Fatimah Mernissi, perempuan dipandang sebagai penyebab terjadinya penyimpangan seksual. Hal ini banyak bersumber dari pemakaian yang salah kaprah terhadap kisah dalam al-Qur'an mengenai Nabi Yusuf yang digoda oleh Zulaikha. Dalam Qs. Yûsuf (12): 8 disebutkan inna kaydakunna 'azhîm (sesungguhnya muslihatmu sangat hebat). Potongan ayat inilah yang digunakan oleh para ulama yang bias gender untuk melihat perempuan sebagai penggoda dan penawar diri bagi perbuatan zina. Seksualitas perempuan dianggap sebagai penghancur tatanan masyarakat yang bermoral. Potongan ayat di atas selalu dimaknai sebagai "kekuatan subversif kaum perempuan untuk menimbulkan kekacauan melalui seksualitas, sensualitas, dan kemampuan rayuan mereka."9

Selanjutnya, karena kekuatan subversif perempuan (qa'id) tersebut menghancurkan tatanan sosia yang bermoral maka muncullah institusi hijab. Institusi hijab secara politis digunakan untuk menjauhkan perempuan dari ruang publik yang bertujuan

${ }^{8}$ Ellen Willis, "Feminism, Moralism and Pornography," dalam Debating Sexual Correctness: Pornography, Sexual Harrasment, Date Rape and The Politics of Sexual Equality, ed. Adele M. Stan (Newyork: Dell Publishing, 1995), 43

${ }^{9}$ Lihat, Fatimah Mernissi, Pemberontakan Wanita: Peran Intelektual Kaum Wanita dalam Sejarah Muslim,” ter. Rahmani Astuti (Mizan: Bandung, 1999), 113-4. 
melindungi mereka dari hal-hal yang tidak diinginkan. Konsep hijab lalu beranjak jauh dari sekedar sebuah mode berpakaian, sebagaimana yang diwahyukan dalam Qs. al-Ahzzâb (33): 59, tetapi menjadi sebuah institusi politik yang membatasi bahkan melarang akses perempuan kepada sumber-sumber kekuatan yang seharusnya mereka miliki, semisal pendidikan dan partisipasi politik. ${ }^{10}$

Politisasi konsep hijab atau jilbab inilah yang mendorong banyak feminis muslim menentang jilbab sebagai kewajiban dan keharusan bagi perempuan. Tahar Haddad misalnya, seorang feminis dari Tunisia, menolak kewajiban berjilbab bagi perempuan karena hal itu adalah bentuk alienasi terhadap perempuan. ${ }^{11}$ Muhammad Sa'îd al-Asymâwî dengan sangat tegas pula melakukan kritik terhadap jilbab sebagai kewajiban keagamaan bagi perempuan. Menurutnya, salah satu prinsip etik hukum Islam adalah 'adam al-ikrah (tidak ada paksaan). Jika agama saja tidak boleh dipaksa mestinya tidak ada paksaan pula dalam implementasi hukum-hukum maupun kewajibannya. ${ }^{12}$ Tentu saja pendapat para feminis muslim itu tidak bisa ditelan mentah-mentah. Masih sangat terbuka lebar ruang untuk mendebat kesimpulan tersebut. Misalnya saja dalam konteks Indonesia di mana pemakaian jilbab menjadi sesuatu yang harus diperjuangkan oleh kaum perempuan sendiri dan bukan paksaan yang diinstitusionalisasi secara top-down (kecuali fenomena di Aceh baru-baru ini), maka jilbab menjadi isu lain. Jilbab lalu menjadi kesadaran yang tumbuh dari dalam diri perempuan yang bisa jadi merupakan suatu bentuk berpakaian yang mempunyai nilai tersendiri bagi kaum perempuan. Menarik pula apa yang diungkap oleh Abdun Nasir lewat penelitiannya di Belanda,

${ }^{10}$ Ibid, 115.

${ }^{11}$ Pengantar Andree Feilard dalam Husein Muhammad, Fiqh Perempuan: Refleksi Kiai atas Wacana Agama dan Gender (Yogyakarta: LKiS, 2001), xvi.

${ }^{12}$ Muhammad Sa'îd al-Asymâwiî, Kritik atas Jilbab, ter. Novrianti Kahar dan Opie Tj. (Jakarta: JIL dan The Asia Foundation, 2003), 18. 
bahwa walaupun secara umum perempuan muslim di Belanda melihat hijab sebagai kewajiban dan simbol jati diri muslimah tetapi keputusan mereka untuk memakai atau tidak lebih banyak dipengaruhi oleh pengalaman dan kecenderungan individu. Banyak juga di antara perempuan muslim di Belanda yang memandanga bahwa hijab tetap sejalan dengan modernitas karena mereka tetap bisa aktif dan terlibat dalam kegiatankegiatan sosial profesional dan tidak terhambat oleh mode berpakaian mereka. ${ }^{13}$

Lebih dari itu, menurut penulis, jika pemikiran al-Asymâwî ditelusuri lebih lanjut maka sebenarnya ada beberapa poin yang menjadi prasyarat bagi penggunaan jilbab oleh perempuan, dalam arti al-Asymâwî tidak menolak secara total jilbab (Qs. alAhzâb [33]:59) atau hijab (Qs. Al-Sajadah [32]: 53) atau khimâr (Qs. Al-Nûr [24]:31) itu sendiri tetapi perlu ada pre-kualifikasi yang menyertainya, yaitu: (a) Tidak ada politisasi bagi kewajiban beragama, termasuk berjilbab; (b) Jilbab hendaknya dipandang sebagai konsep yang bermuatan etika dan estetika daripada substansi ajaran Islam itu sendiri; (c) Jilbab adalah simbol yang harus diperluas menjadi substansi, sehingga menutup aurat lewat simbol jilbab hendaknya disertai dengan kesopanan pribadi dan tidak berlebih-lebihan di dalam berbusana. Apapun dasar argumen pihak yang mengkritisi jilbab, menurut penulis, dapat ditarik benang merah bahwasanya tubuh wanita tidak perlu dikontrol secara struktural sistematis tetapi perlu dikembalikan menjadi kesadaran sejati dari perempuan itu sendiri. Selain itu, kasus-kasus penyimpangan seksual tidak harus serta merta dialamatkan kepada perempuan sebagai satu-satunya sumber dan pihak yang harus bertanggung jawab karena sebenarnya pada saat yang sama perempuan juga menjadi korban. ${ }^{14}$

${ }^{13}$ Mohammad Abdun Nasir, “ Muslim Female Students' Views on Hijab in the Netherlands," Jurnal Ulumuna, 1 (Januari-Juni, 2004), 47-67.

${ }^{14}$ Walaupun para pejuang feminisme radikal sepakat bahwa pornografi merugikan dan mengorbankan kaum perempuan, tetapi mereka berbeda 
Sekilas, seolah feminisme radikal bersikap ambivalen terkait dengan masalah pendekatan politik atau konstitusional terhadap pornografi. Di satu sisi aliran ini menganggap bahwa politik apapun sebagai representasi dari kepentingan yang berkuasa selalu menyodorkan kepentingan pihak tersebut sehingga mereka meragukan (baca: bukan menolak) upaya legal formal untuk meminimalisir pornografi. Tetapi di sisi lain, aliran ini tidak bisa terhindar dari upaya hukum sebagai salah satu strategi gerakannya. Inilah yang penulis maksud dan dijelaskan sebelumnya bahwa ketidaksetujuan aliran ini terhadap corak analisis dan gerakan feminisme liberal yang bertitik tolak pada upaya hukum, bukan berarti penolakan total. Upaya hukum untuk meminimalisir pornografi sebenarnya bisa saja ditempuh apabila memenuhi syarat-syarat berikut ini: 15

a. Aturan hukum tidak semakin menyuburkan industri pornografi;

b. Aturan hukum tidak double-standard; hanya menuding perempuan sementara laki-laki sebagai pelaku tidak disentuh;

c. Penolakan pornografi oleh aturan hukum harus berdasarkan alasan bahwa ia adalah kekerasan terhadap perempuan;

pendapat tentang cara bagaimana menghentikan laju dan derasnya pengaruh pornografi. Kelompok pertama, misalnya Andrea Dworkin, memilih untuk mengutamakan jalur konstitutional dengan mengusulkan pembentukan civil right legislation (UU Hak Sipil) untuk meminimalisir pornografi. Lihat Andrea Dworkin, "Pornography is a Civil Right Issue," dalam Debating Sexual Correctness: Pornography, Sexual Harrasment, Date Rape and The Politics of Sexual Equality, ed. Adele M. Stan (Newyork: Dell Publishing, 1995), 35-37. Kelompok kedua, misalnya Elen Willis memandang, pendekatan hukum tidak akan bisa berbicara banyak karena hukum itu sendiri pasti patriarkhis. Yang paling utama dan efektif, menurut kelompok ini, untuk meminimalisir pornografi adalah dengan melakukan penyadaran baik terhadap perempuan yang utamanya sebagai korban maupun terhadap pelaku intensif industri pornografi dan pornoaksi dalam berbagai bentuknya. Ellen Willis, "Feminism, Moralism and Pornography..., 48. In a male-supremacist society the only obscenity law that will not be used against women is no law at all.

${ }^{15}$ Dworkin, "Pornography is a Civil..., 35-37. 
d. Aturan hukum tidak memuat kebencian terhadap perempuan (women-hating) baik secara implisit maupun eksplisit.

Keragu-raguan feminisme radikal untuk menggunakan pendekatan konstitusional, tampaknya bukan pada problem model pendekatannya itu sendiri, tetapi lebih pada pertanyaan apakah aturan hukum yang terbentuk oleh sistem yang dipenuhi oleh colluders (pihak-pihak yang berkolusi dan berkepentingan) itu akan benar-benar memenuhi syarat-syarat sebagaimana yang mereka usulkan pada poin-poin tersebut di atas.

Jadi jelaslah bahwa penolakan beberapa kalangan feminisme (atau yang menamakan dirinya pejuang perempuan) terhadap RUU APP yang terjadi di Indonesia, misalnya, pada dasarnya bukan sikap pro pornografi. Penolakan tersebut lebih sebagai upaya ketidaksetujuan golongan ini terhadap RUU APP yang selalu menempatkan perempuan sebagai pihak yang bersalah. Perempuaan diasumsikan sebagai penanggungjawab utama dan penuh terhadap kehancural moral. Hal ini tentu saja bukan cara pandang yang komprehensif menurut kalangan feminis, karena perempuan tidak lebih hanya sebagai korban. Menunjuk jari terhadap perempuan untuk sekedar berhenti dari dunia pornografi tidak menyelesaikan akar masalah, ibarat mematikan nyala api hanya lewat kobarannya bukan lewat baranya. Sebenarnya yang paling mendasar adalah merubah cara pandang dunia patriarkhi dan industri mesum terhadap posisi perempuan sebagai obyek. Tak ayal, perempuan pun perlu disadarkan untuk menentang arogansi dunia patriarkhi dalam hal ini. Bahkan menurut kalangan feminisme radikal, perempuan hendaknya menjadi avant-graders issue menentang pornografi.

\section{Pornografi versus Kebebasan}

Pornografi sebenarnya menganggap perempuan bukan sebagai manusia bebas, bahkan bukan sebagai manusia itu sendiri. Pornografi adalah sebuah tindakan kolonialisasi dan dehumanisasi perempuan. Bagi feminisme radikal, mereka yang 
mengatasnamakan pornografi sebagai kebebasan, adalah mereka yang tidak pernah menggunakan akal sehatnya untuk melihat masalah pornografi. Bagaimana mungkin pornografi dianggap sebagai kebebasan jika pada dasarnya pornografi adalah sebuah tindakan pemerkosaan dan penyiksaaan terhadap perempuan (they won't accept the hatred and the rape of women as anybody's idea of freedom). ${ }^{16}$ Membebaskan dunia dari pornografi, dengan demikian, adalah penghapusan kekerasan terhadap perempuan dan mengembalikan posisi kemanusiaan perempuan yang bebas berkehendak mengontrol dirinya sendiri.

Pornografi bukan ekspresi kebebasan karena sesungguhnya dalam pornografi terjadi objektifikasi tubuh dan naluri seks perempuan. Obyektifikasi itu sendiri menyimpan upaya dehumanisasi dan kolonialisasi perempuan. Dehumanisasi adalah menjadikan perempuan tidak sebagai manusia yang punya kehendak dan naluri independen, tetapi lebih sebagai subbuman yang pantas diberlakukan sesuai kehendak dan kepentingan orang lain. ${ }^{17}$ Kolonialisasi adalah menjadikan perempuan sebagai obyek yang dijajah yang bebas diarahkan untuk kepentingan penjajah yaitu dunia patriarkhi. Ketika pornografi itu menempatkan perempuan sedemikian rupa, lalu lewat pintu manakah ekspresi kebebasan dapat dimasukkan dalam isu pornografi?

Mungkin saja perempuan merasa bebas karena menganggap bahwa dengan keterlibatan mereka dalam pornografi berarti mereka telah melakukan apapun yang dia inginkan, tubuh mereka adalah milik mereka sehingga apapun yang mereka lakukan itu adalah hak yang tidak dapat diganggu gugat. Pandangan semacam ini sebenarnya adalah karena perempuan

16Ibid., 40

${ }^{17}$ Lebih jauh tentang ini lihat, Martha C Nussbaum, Women and Human Development (Cambridge: Cambridge University Press: 2000), dan karyanya yang lain berjudul Sex and Social Justice (New York: Oxford University Press: 1999). 
itu sendiri tidak menyadari bahwa ada kekuatan lain di luar diri mereka yang telah tersistematisasi sedemikian rupa sehingga seakan-akan mereka yakin bahwa mereka melakukan tindakantindakan porno itu di alam kesadaran mereka. Aliran Marxian menyebutkan kesadaran yang demikian sebagai false consciousness, yaitu kesadaran yang sengaja dibentuk oleh pihak yang berkuasa (who are in power). ${ }^{18}$ Karena terbentuk sedemikian rupa maka pihak-pihak tertentu yang tidak berkuasa lalu merasa bahwa apa yang dialaminya adalah memang seharusnya demikian. Perempuan tidak menyadari bahwa kehidupan di dunia patriarkhi yang mereka jalani berlangsung sesuai dengan kehendak master narrative. Kehidupan ini selalu diarahkan oleh narasi seorang master yang dianggap sebagai satu-satunya narasi yang absah dari rentang sejarah kehidupan manusia.

Berbicara tentang sistematisasi subordinasi di satu pihak dan kebebasan (freedom) atau hak (agency) menentukan kehidupan perempuan oleh perempuan itu sendiri pada isu pornografi memang sangat sulit dan seolah tidak berujung. Kesulitan itu muncul karena feminisme, khususnya feminisme radikal, pada umumnya selalu melihat bahwa apapun alasannya, perempuan adalah korban dan objek di hadapan keangkuhan budaya dan politik patriarkhi. Sepertinya sangat sedikit, untuk tidak mengatakan tidak ada sama sekali, celah bagi perempuan untuk berposisi sebagai subjek. Ini ironis! Padahal sesungguhnya seperti apa yang pernah disampaikan Rousseau, bahwa sebenarnya permasalahan sexuality, misalnya, adalah the potential power of women. Dia menuturkan bahwa perempuan telah ditakdirkan untuk menjadi perangsang nafsu laki-laki, oleh karenanya laki-laki harus mencoba untuk menyenangkan perempuan jika keinginan nafsu mereka hendak dipenuhi. ${ }^{19}$

${ }^{18}$ Lihat Lois Tyson, Critical Theory Today (New York: Garland Publishing, Inc., 1999), 55.

${ }^{19}$ Zillah R. Eisenstein, The Radical Future of Liberal Feminism (New York: Longman:1981), 62. 
Lebih jauh, Rousseau menambahkan bahwa walaupun dalam beberapa aspek, kehidupan perempuan memang dependent terhadap laki-laki tetapi khusus masalah seksualitas sebenarnya laki-laki sangat dependent terhadap perempuan. Kekuatan perempuan lewat potensi seksual ini sebenarnya bisa digunakan oleh para feminis untuk memperjuangkan posisi perempuan sebagai subyek yang mampu mengarahkan potensi seksualitas mereka sebagai kekuatan pengontrol, baik terhadap dirinya maupun terhadap laki-laki. Bukan sebaliknya, justru potensi kontrol lewat seksualitas ini, lagi-lagi, disalah-posisikan menjadi pendukung obyektifikasi perempuan itu sendiri.

\section{Politik Patriarkhi}

Dalam pandangan feminisme radikal, tidak bisa dipungkiri bahwa pornografi adalah bentukan dari sistem patriarkhi yang melihat perempuan semata-mata sebagai obyek keindahan, inspirasi seni, dan korban empuk dari kehausan birahi dunia industri. Pihak-pihak yang terlibat dalam industri ini mengatasnamakan pornografi sebagai forum hiburan, kesenangan, dan ekspresi kebebasan. Tentu saja kebebasan yang dimaksud hanya milik mereka yang memperlakukan pornografi sebagai kebebasan dan kesenangan. Perempuan dibius sehingga mereka seakan-akan rela menyodorkan tubuhnya untuk ditelanjangi, dieksploitasi, dan dipajang. Perempuan yang tidak terlibat dirayu untuk mengimitasi apa yang dilakukan oleh rekan perempuan mereka. Pada akhirnya, yang terlihat dipermukaan adalah perempuan sangat menyukai dan menikmati eksploitasi itu bahkan meminta untuk tidak dihentikan.

Kenapa perempuan, sesungguhnya, adalah korban? Padahal mereka senyatanya adalah pelaku? Bagi aliran ini, ketimpangan power antara perempuan dan laki-laki di dunia patriarkhis telah membungkam perempuan untuk menolak tawaran-tawaran yang membius mereka. Perempuan tidak berdaya, bagaimana mungkin perintah tuan ditolak oleh hamba sahaya? Pornografi 
semakin membungkam perempuan dan menjadikan perempuan sebagai subbuman. Tubuh perempuan sepenuhnya dikontrol oleh pihak-pihak yang berkuasa. Kalaupun ada upaya untuk meminimalisir pornografi, maka biasanya dunia patriarkhi malah melindungi pihak-pihak yang mengeksploitasi dan melakukan kekerasan terhadap perempuan itu sendiri, bukan menyelamatkan perempuan dari kejahatan sistem eksploitasi itu sendiri.

Sistem patriakhi ini didukung oleh enam komponen utama yang berkolusi melanggengkan pornografi dan bahkan menciptakan pornografi itu sebagai kebutuhan perempuan. Mereka adalah: ${ }^{20}$

a. Industri yang meraup keuntungan lewat pornografi;

b. Media cetak maupun elektronik yang selalu mempublikasikan pornografi;

c. Politisi yang tidak mendukung upaya-upaya penghapusan pornografi sebagai sebuah bentuk kekerasan terhadap perempuan;

d. Para penasehat hukum yang selalu membela kepentingan para pelaku eksploitasi terhadap perempuan;

e. Komisi hukum yang memprakarsai Obscenity Laws (UU Pornografi) yang notabene menempatkan tubuh perempuan sebagai pelaku utama pornografi dan satu-satunya yang perlu di atur.

f. Terakhir dan yang terpenting adalah para pihak penikmat (consumer) pornografi.

Para pihak yang berkolusi memapankan pornografi tersebut di atas dapat berupa kekuatan yang tersistematisasi sedemikian rupa seperti dunia industri, atau juga kecenderungan personal seperti para penikmat pornografi. Kedua bentuk tersebut samasama sulit untuk dikendalikan. Dunia industri dipenuhi oleh kepentingan berbagai pihak. Demikian pula, pada tingkat

${ }^{20}$ Dworkin, "Pornography is a Civil ..., 35-37 
individu, para penikmat itu sulit dijerat karena mereka sebenarnya bersembunyi di balik argumen privacy dan hak pribadi.

\section{Catatan Akhir}

Feminisme radikal memandang bahwa hanya ada satu cara untuk meminimalisir pornografi, yaitu dengan membebaskan perempuan dari dominasi sistem yang dimiliki oleh laki-laki. Sulit memang, tetapi itu semua mungkin, dan memerlukan proses dekolonialisasi yang mendalam. Dan perempuan itu sendiri harus memulai, melakukan, bahkan menjadi pihak terdepan menantang dominasi pria.

Perempuan tentu tidak perlu menunggu belas kasihan lakilaki. Untuk memposisikan perempuan secara setara dengan laki laki, menurut Catharine A. MacKinon, perlu dilakukan dominance approach, yaitu bukan dengan mengemis penyamaan itu dari lakilaki tetapi dengan merebut kekuasaan yang didominasi mereka agar terdistribusi secara adil dan jujur. MacKinon menegaskan usulannya ini dengan kata-katanya yang terkenal: "take your foot off our neck, then we will hear in what tongue women speak," 21 (Lepaskanlah kakimu dari leher kami, kita lalu akan mendengar bagaimana perempuan berbicara). Yang diperlukan oleh perempuan adalah kesempatan dan ruang yang lebih lebar untuk berpartisipasi dalam dunia yang juga turut mereka miliki.

Proses dekolonialisasi dan perebutan kekuasan tersebut walaupun, mungkin, terdengar simple tetapi dalam tahapan pelaksanaan sangat kompleks dan tidak gampang, apa lagi kalau perempuan memang ditekankan untuk menjadi pelaku utama dalam upaya ini. Di sinilah menurut penulis, letak inkonsistensi feminisme radikal. Sebagaimana yang disebutkan sebelumnya

${ }^{21}$ Catharine A. MacKinnon "Difference and Dominance: On Sex Discrimination," dalam Gender and American Law: Feminist Legal Theories (New York: Garland Publishing, Inc:2000). 
bahwa pada isu pornografi, aliran ini menganggap bahwa perempuan semata-mata sebagai obyek. Karena obyek maka mereka sesungguhnya adalah korban. Posisi perempuan sebagai obyek di sini seakan-akan menafikan bahwa sesungguhnya perempuan punya kekuatan untuk mencegah terjadinya pornografi. Pada poin ini sebenarnya seakan-akan aliran ini sangat pesimis dan meragukan kemampuan perempuan sendiri untuk berbuat menentang pornografi ini. Padahal ketika sampai pada upaya menolak dan meminimalisir pornografi, aliran ini menggugah dan mendorong perempuan untuk menjadi avantgraders. Pada proses ini tampaknya konsep power yang di pakai oleh aliran ini adalah konsep power ala Michael Foucault. Menurut Foucault, bahwa power itu tidak hanya berada pada posisi atas atau penguasa tetapi bahwa kekuasaan itu bersirkulasi pada segala arah, kepada dan dari seluruh tingkatan sosial, setiap saat. ${ }^{22}$ Oleh karenanya, jika perempuan dipandang punya kekuatan untuk memerangi pornografi, perempuan seharusnya juga diyakinkan bahwa mereka mempunyai kekuatan untuk mengontrol potensi seksualitasnya sehingga tidak semata-mata menjadi obyek bagi nafsu seks dunia patriarkhi. Tetapi justru sebagai potensi untuk mengontrol liarnya kebutuhan dunia patriarkhi yang mengorbankan sifat kemanusiaan perempuan. Oleh karenanya, seyogyanya perempuan berperan dalam upaya mencegah sekaligus memerangi terjadinya pornografi.

Selain itu, kesimpulan feminisme radikal yang memandang perempuan sebagai obyek di satu sisi dan avant-graders pembasmian pornografi juga tidak dilengkapi dengan tawarantawaran aplikatif. Katakanlah bahwa tubuh perempuan memang indah dan selalu menjadi stimulan birahi kaum laki-laki, tetapi what to do next by those women itu belum diformulasikan. Mungkin laki-laki memang perlu di dorong untuk tidak haus dan rakus terhadap keindahan dan stimulus tersebut, tetapi tentu

22Tyson, Critical Teory..., 281. 
perempuan juga perlu berbuat sesuatu untuk bertanggungjawab. Misalnya lewat tawaran alternatif tentang bagaimana perempuan harus menunjukkan identitas dirinya yang memang berharga.

Menarik misalnya apa yang disampaikan oleh Fadwa el Guindl bahwa sesungguhnya perempuan muslim meneguhkan identitas keagamaannya lewat cara berpakaian itu sesungguhnya bertujuan mengontrol tubuh mereka sendiri dan menolak obyektifikasi dunia publik terhadap privacy mereka. ${ }^{23}$ Pengutipan pendapat Guindl di sini bukan bermaksud 'memaksa' aliran ini untuk mengimpor budaya Islam, untuk diselipkan sebagai bagian dari keseluruhan analisis mereka tentang pornografi, khususnya cara berpakaian. Pertama, karena etika berpakaian dalam Islam pun masih debatable dan multi-interpretasi. Kedua, jilbab misalnya sebagai etika berpakaian dalam Islam, dalam batas tertentu, juga di pandang sebagai penyerahan tanggungjawab dan beban kontrol moral hanya kepada perempuan. Ketiga, tentu tidak bijak budaya yang berasal dari dasar filosofis yang berbeda diterapkan pada budaya lain. Tetapi paling tidak, agar perjuangan feminisme radikal menentang pornografi lebih fokus, hendaknya disertai dengan tawaran langkah-langkah operasional dan realistis untuk perempuan itu sendiri, semisal dengan merumuskan bagaimana cara perempuan menjaga performance mereka agar tidak siap dimangsa oleh nafsu bejat pihak-pihak tertentu.

Di atas itu semua, celah untuk mengkritik memang selalu ada. Tetapi yang penting, di mana feminisme radikal dianggap berjasa, adalah keberhasilan aliran ini menteorisasikan pornografi sebagai tindakan kekerasan terhadap perempuan, meng-bighlight budaya patriarkhi sebagai penyebab utamanya, dan mengusulkan upaya dekolonialisasi perempuan sebagai solusi atas dehumanisasi perempuan lewat pornografi di mana perebutan kekuasaan menjadi langkah awalnya.

${ }^{23}$ Fadwa El. Guindl, "Feminism Comes of Age in Islam," dalam Arab Women: Between Defiance and Restraints, ed. Suha Sabbagh (New York: Olive Branch Press, 1996), 15-21. 


\section{Daftar Pustaka}

Andrea Dworkin, "Pornography is a Civil Right Issue," dalam Debating Sexual Correctness: Pornography, Sexual Harrasment, Date Rape and The Politics of Sexual Equality, ed. Adele M. Stan (Newyork: Dell Publishing, 1995).

Andree Feilard, "pengantar" dalam Husein Muhammad, Fiqh Perempuan: Refleksi Kiai atas Wacana Agama dan Gender (Yogyakarta: LKiS, 2001)

Audre Lorde, "The Master's Tools Will Never Dismantle the Master's House," dalam This Bridge Called My Back: Writings by Radical Women of Color, ed. Cherrie Moraga dan Gloria Anzaldua (New York: Kitchen Table/Women of Color Press, 1983).

Adelle M. Stan (ed.), Debating Sexual Correctness: Pornography, Sexual Harrasment, Date Rape and The Politics of Sexual Equality (New York: Dell Publishing, 1995).

Catharine A. MacKinnon, "Sex and Violence: A Perspective," dalam Feminism Unmodified, ed. Catharine A. MacKinnon (Cambridge: Harvard University Press: 1987).

"Difference and Dominance: On Sex

Discrimination," dalam Gender and American Law: Feminist Legal Theories (New York: Garland Publishing, Inc: 2000). ,Catherine A. MacKinnon, Toward a Feminist Theory of the State (Cambridge: Harvard University Press, 1989).

D. Kelly Weisberg, "Introduction" dalam Feminist Legal Theory: Foundations, (Philadelphia: Temple University Press, 1997). Ellen Willis, "Feminism, Moralism and Pornography," dalam Debating Sexual Correctness: Pornography, Sexual Harrasment, Date Rape and The Politics of Sexual Equality, ed. Adele M. Stan (New York: Dell Publishing, 1995).

Fadwa El Guindl, "Feminism Comes of Age in Islam," dalam Arab Women: Between Defiance and Restraints, ed. Suha Sabbagh (New York: Olive Branch Press, 1996). 
Fatimah Mernissi, Pemberontakan Wanita: Peran Intelektual Kaum

Wanita dalam Sejarah Muslim," ter. Rahmani Astuti (Mizan: Bandung, 1999).

Judith Lorber, Gender Inequality: Feminist Theories and Practice (California: Roxbury Publishing Company, 2001).

Lois Tyson, Critical Theory Toda (New York: Garland Publishing, Inc., 1999).

Marcia Ann Gilespie et.al, "Where do We Stand on Pornography," dalam Debating Sexual Correctness: Pornography, Sexual Harrasment, Date Rape and The Politics of Sexual Equality, ed. Adele M. Stan (New York: Dell Publishing, 1995).

Martha C Nussbaum, Women and Human Development. (Cambridge: Cambridge University Press:2000). , Sex and Social Justice (New York: Oxford University Press: 1999).

Mohammad Abdun Nasir, " Muslim Female Students' Views on Hijab in the Netherlands," Jurnal Ulumuna, 1 (Januari-Juni, 2004).

Muhammad Sa'îd al-Asymâwî, Kritik atas Jilbab, ter. Novrianti Kahar dan Opie Tj (Jakarta: JIL dan The Asia Foundation, 2003).

Zillah R. Eisenstein, The Radical Future of Liberal Feminism (New York: Longman:1981). 